\title{
U.S. Monetary Hegemony after the Collapse of the Bretton Woods System
}

\author{
Jiarui Wu \\ University of California, Irvine, CA 92612, USA \\ Jiaruw4@uci.edu
}

\begin{abstract}
The Bretton Woods system (1944) founded inextricable monetary connections between the U.S. and many countries around the world, including Canada, Australia, and most Western European countries. It enabled the U.S. to build up its monetary hegemony in the world, possessing great influence on the global currency market. Since there were various limitations that existed in the inherent structure of the system and the U.S.'s inabilities to master the global market, the Bretton Woods System collapsed in less than 30 years. Nevertheless, though the Bretton Woods System ended in 1971, the U.S. did not lose its dollar hegemony and still owned considerable advantages in its monetary supremacy. This paper will provide the context of the Bretton Woods System of monetary management. Significantly, I will explore the reasons that gave rise to the U.S.'s continuous monetary hegemony, the pros and cons of dollar hegemony, and its expected challenges.
\end{abstract}

Keywords: The Bretton Woods System; Dollar Hegemony; Gold; Inflation; Global Market.

\section{Introduction}

In 1944, the United States and other global powers held negotiations on building financial and commercial relations, leading to the formation of the Bretton Wood System. Under this system, the U.S. dollar was based on gold, and other currencies were pegged on the dollar's value. The U.S. stimulated the development of its monetary hegemony in the international currency market through the establishment of the system, but the immanent limitations of the system and incapacity of the U.S. to control the global market led to its downfall. In 1971, the U.S. terminated the dollar's convertibility to gold, marking the end of the Bretton Wood System. Remarkably, the U.S. monetary hegemony did not collapse with the decay of the system. This paper provides a brief history of the Bretton Wood System and the factors that contributed to its downfall. Additionally, the paper will explore reasons why the U.S. monetary hegemony survived despite the system's collapse. Finally, the paper will delve into the strengths and shortcomings of the dollar hegemony and the expected challenges.

\section{The Bretton Woods System}

The Bretton Woods System was formed through articles of alliance in a conference organized by the United States at Bretton Woods' Mount, Washington Hotel, in 1944. This was the first negotiated monetary order that aimed at governing monetary relations between independent nations at the height of World War II (Ikenberry 156). The system sought to establish financial and commercial relations among the U.S., Western European countries, Canada, Japan, and Australia. The system was also established to deal with perceived interwar period challenges like beggar-thy-country devaluation, protectionism, unstable exchange rates, and hot money flows. Furthermore, the Bretton Woods System sought to establish financial and monetary stability, enhance global economic growth and facilitate international trade.

Architects of the System compromised between the fixed exchange rates used in the gold standard, which were perceived as effective in establishing a global finance and trade network, and the flexibility which nations had adopted in the 1930s to reestablish domestic financial and economic stability (Ikenberry 158). The system's articles were an amalgamation of Dexter's and Keynes' plan. The compromise led to an adjustable peg system that attached a dollar to ounces of gold. Additionally, the negotiation gave member countries exchange rate solidity and monetary system autonomy. Consequently, the international monetary fund, which is anchored on the credit union principle, was 
formed to allow member countries to withdraw in excess of their gold quotas and offer reprieve for short-term account deficits.

The Bretton Woods System took fifteen years to become a fully operational gold dollar standard. As the system rolled out, three key challenges became evident - confidence, adjustment, and liquidity problems. The adjustment challenge reflected downwards wage and price rigidity that prevented the gold standard's operation and normal price adjustment. The problem was witnessed in the United Kingdom, which alternated between the fiscal and expansionary monetary policy and austerity measures due to the prevailing economic crisis. The second challenge was due to the asymmetrical adjustments between the American currency and that of other countries. Since the U.S. acted as the central reserve, it did not adjust for its payment deficit balance, which caused resentment from European countries.

The United States became concerned about the growing balance of payment deficit and its effect on the world's confidence. As the country's dollar liabilities mounted abroad, there was a likelihood that they would be changed into gold, resulting in the reduction of the U.S.'s monetary gold stock to a level that could trigger a run (Ouyang et al. 956). By 1959, the U.S.'s dollar gold stocks were equal to their external dollar liability. Furthermore, the rest of global gold stock exceeded those held by the United States by 1964. Another concern was the role of the dollar in providing global liquidity. As urged by some European countries, the elimination of the United States' balance of payment deficit would have led to a global liquidity shortage.

The main factor that led to the collapse of the Bretton Woods System was the rising inflation in the uses beginning in 1965 (Bordo et al. 1030). Before this year, the U.S. maintained low inflation and attached significance to the balance of payment deficit and the monetary gold stock. After 1965, the U.S. shifted to an inflationary policy. This policy shift was a reflection of the rising fiscal deficits due to the Vietnam War. The shift of the Federal Reserve's stance in mid-1960 was also due to the influence of Keynesian economics that emphasized full employment and the notion that the Reserve can manage the Philips Curve trade-off between unemployment and inflation.

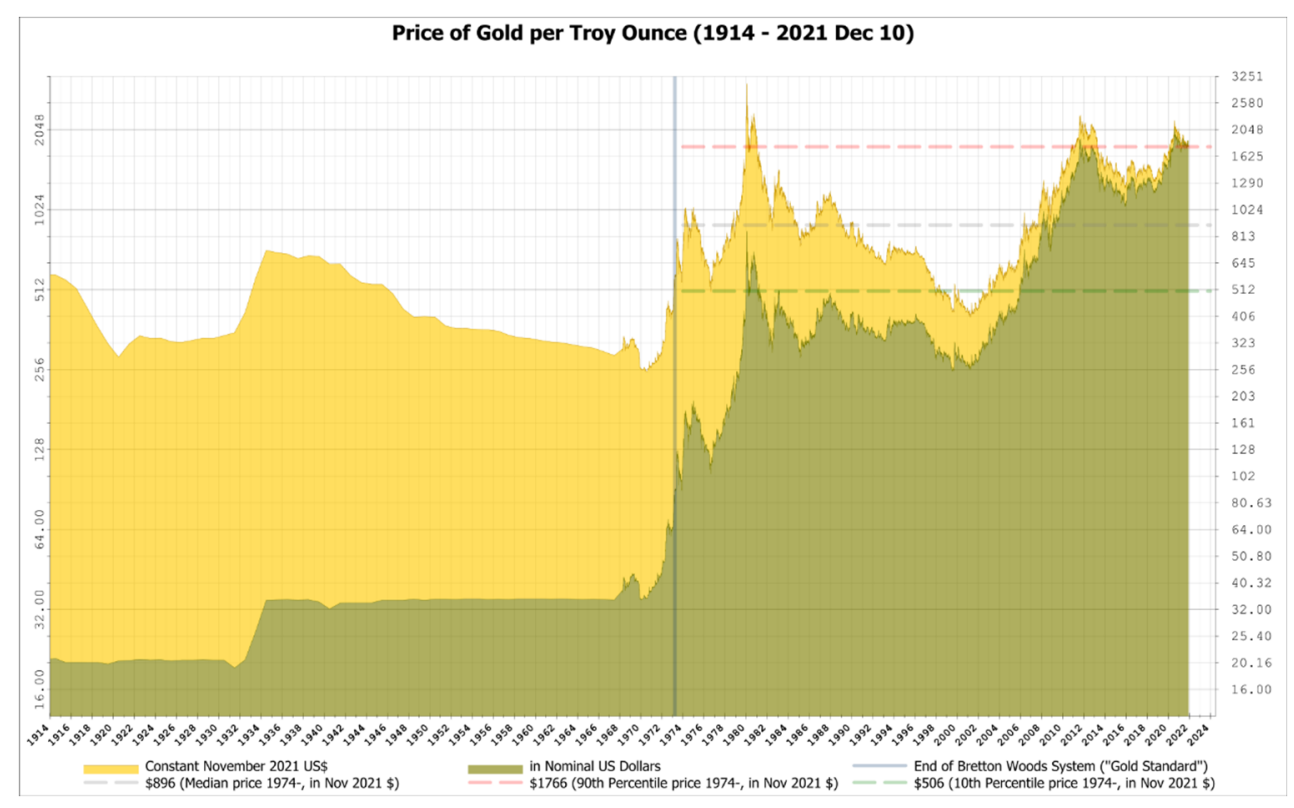

Figure 1. Global gold price showed the collapse of the Bretton Woods System

The United States monetary growth caused inflation which later spread globally through the balance of payment deficits. Consequently, European countries like Germany experienced a balance of payment surplus. German financial authorities unsuccessfully tried to sterilize inflow, prompting a rise in inflationary pressure. After the 1967 devaluation of the euro, pressure against the dollar mounted through the London gold exchange, leading to the disbandment of the Gold Pool in 1968 (Bordo et al. 1035). A two-tier arrangement then replaced the gold pool. In the subsequent years, 
America pressured other monetary authorities and prevented them from converting their dollars safe assets into gold. Therefore, the main reason behind Bretton Woods System's failure was the inflationary monetary policy that was unsuitable to the key currency nation. The Bretton Woods System required nations to follow the fiscal and monetary policies in line with the official peg, and the U.S. dishonored this principle in 1965.

\section{Reasons Why the Dollar Hegemony Survived and Still Possessed Advantages}

Surprisingly, even though a run on the dollar caused the failure of the Bretton Woods System, it led to an era of the dollar hegemony or global dollar standard that exists to this day. Since 1971, the supremacy and centrality of the U.S. dollar have considerably increased in all dimensions. Part of the rising importance of the dollar somewhat mechanically reflects the collapse of the Soviet bloc and the shift of these centrally planned economies to market principles, accompanied by financial and trade liberalization (Gourinchas 45). Immediately after the Bretton Woods System collapsed, many Asian countries, including China, Singapore, Pakistan, and Indonesia, anchored their currencies against the U.S. dollar. Other countries like Vietnam, India, and Malaysia followed suit between 1975 and 1994. Most of these countries had previously anchored their currencies against the sterling pound.

A possible interpretation of this shift is that anchoring against the sterling was largely illusory. In the Bretton Woods System era, all currencies, including the sterling, had a fixed rate against the dollar. Small changes in the par values or major world currencies happened between 1955 and 1969. The sterling was devalued in 1967, France devalued three times between 1958 and 1969, and Germany twice revalued its currency in 1961 and 1969. As a result, anchoring to the sterling, the dollar, or pegging any currency to the latter must have been economically equivalent and difficult to detect empirically. In other words, most Asian countries might have been shadow anchoring against the dollar. Therefore, the Bretton Woods System's collapse only manifested what had for long been an economic reality.

The shadow anchoring concept helps explain how the dollar remained strong after the system's collapse. Some traditional interpretations of this concept emphasize the lack of an alternative. For instance, Mundell (390) notes that "the dollar could survive the crisis of 1971 as it did prove its growing secular strength despite its short-term weakness. When the United States suspended convertibility, the dollar was still the world unit of account." This is why many nations went back to the dollar system after 1971 because they lacked an alternative.

Regardless of the formal rules in play, international monetary systems operate asymmetrically, whereby large global asset producers are at the center. The Bretton Woods System architects attempted to deal with asymmetry by first fixing the dollar's value against gold (Prates et al. 55). Secondly, the fixed parities operated with limited capital mobility. Constraining capital mobility helped limit the demand for U.S. safe assets from foreign investors. Fixed parities ensured that local alternatives that were equivalent to dollars existed. Therefore, while local financial institutions had no option but to hold local assets in place of U.S. dollars, the two were equivalent and local assets 'shadowed' dollar assets. Therefore, even if the U.S. dollar was scarce, acutely so in the aftermath of a war, the global economy would smoothly operate in dollar-safe assets, assuaging the underlying dollar scarcity. However, during 1960, the world economy encountered a dollar glut due to the failure of U.S. monetary policy. The fixed exchange rate system required foreign banks to have dollar reserves, propagating the glut of their financial systems. The late 1960s and the early 1970s witnessed an excessive supply of dollar assets into the global economy. The prior dollar depreciation between 1968 and 1973 acted as a corrective mechanism to lessen the market value of dollar assets and create market equilibrium.

The failure of the Bretton Woods System acted as a bridge between gold and the dollar in 1969 and resolved the Triffin dilemma. In 1973, the Smithsonian agreement failed, linking the dollar and other world currencies. This environment was marked by progressively porous capital controls and the rise of offshore dollar markets. From 1973, the safe asset demand relocated to the dollar asset 
because the United States was the only provider of worldwide safe assets. The shift to the dollar currency after the Bretton Woods System's collapse helped maintain the monetary hegemony.

The dollar dominance after the collapse was due to its capacity to mitigate several risks that the global economy faced. Additionally, the role of multinationals in using the dollar for their transactions led to the dominance of dollar hegemony (Milan 127). Furthermore, the proposal to have the Free Trade ores of the Americas (ALCA) was one mechanism used to maintain hegemony. (Milan 128) describes how internal and external military conflicts have been used as a progressive process of establishing and maintaining U.S. hegemony, fundamentally through mobilization of the U.S.'s enormous production potential. Nonetheless, financial and monetary aspects play a central role in the U.S. dominance. As a result, Milan (128) argues that international financial institutions like the International Monetary Fund (IMF) are instrumental to the dollar hegemony. For instance, loans dominated in dollar currency gave the U.S. a privileged position in governing and managing these institutions.

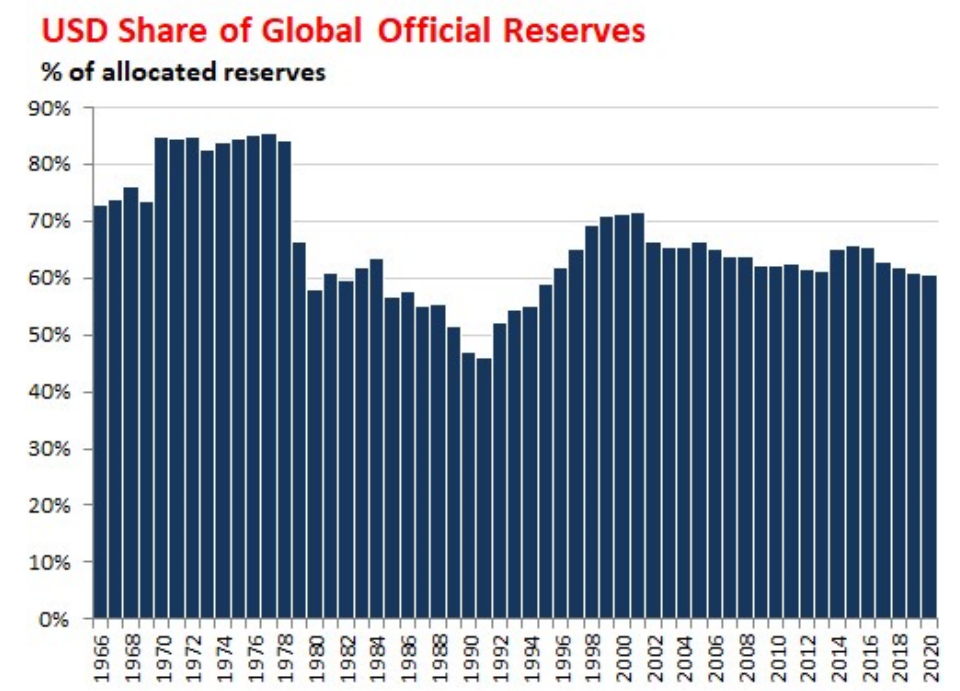

Figure 2. US Dollar Hegenony After the Collapse of the Bretton Woods System (Source: IMF)

\section{Pros and Cons and Possible Challenges of the Dollar Hegemony}

The dollar hegemony enabled the United States to possess the privilege of borrowing money from other nations at a low cost and being able to somehow live beyond its means. Dollar hegemony has enabled the United States to pose as a global economic engine through its spending power. The American financial and banking system and multinationals have greatly benefited from the hegemony. Having a strong currency serving as a reserve of all nations has also given the U.S. soft power over other nations (Blanchard et al. 570). The U.S. can impose sanctions on its adversaries instead of using military force. The strong currency can be used as a weapon against America's geopolitical competitors, as in the case of Iran.

From the perspective of a dollarizing nation, especially the U.S. itself, replacing local currency with the dollar is associated with several benefits, including reduced administrative costs. Governments no longer need to incur the expense of sustaining an infrastructure dedicated to managing and producing another country's currency (Cohen 78). Admittedly, these saving are likely to be attractive to low-income countries. However, even for wealthy nations, the potential of reduced expenses can be considerable.

The dollar hegemony has established a basis for a sounder financial sector. The hegemony not only involves foreign currency adoption but also financial integration with the U.S. Alignment with the U.S. will force local financial systems to enhance service quality and efficiency (Cohen 82). Additionally, dollarization is a commitment to financial transparency, fiscal responsibility, and low 
inflation. This has been of great importance to nations that have not been previously enjoying a good reputation on fiscal and price stability.

The dollar hegemony has also led to the significant decrease of borrowing interest rates. Dollarization leads to a stable relationship because the currency's status is well recognized and secure. Therefore, instead of governments investing in building market confidence in their local currency, they can hire a respected dollar currency.

Despite several advantages of dollar hegemony, the American ruling class has begun to think it brings disadvantages that polarize the politics and economy of the U.S. This impact extends to international levels, leading to social and economic imbalances that are difficult to manage. Hegemony has also led to a speculation-oriented economy. Jobs, especially those related to manufacturing, have been the most affected. A strong dollar has hindered the expansion of the manufacturing base since American products are more expensive than the competition. This aspect has led to imports from abroad. As a result, American production, especially those in a market segment with low-value addition, has been damaged.

The financial crisis behind the dollar hegemony does not only involve the devaluation of a currency against gold or another currency but also the market's loss of confidence in paper currency and a shift to a long-term haven like hard assets and commodities. When nations concertedly or separately employ measures to increase their gold or repatriate gold held overseas, or when they form an agreement to trade on another currency other than the U.S. dollar, these developments pose a significant challenge to the dollar hegemony.

Managing a dominant currency is central to soft powers and influence. The dollar hegemony enables the U.S. to master the world economy and influence its development direction. Monetary supremacy also facilitated the U.S. to reduce its administration costs, prompt the establishment of a sound financial sector, and manipulate borrowing interest rates. The end to the dollar hegemony is unlikely in the near future. However, the possibility of a slow and gradual decline is likely. As other big economic powers challenge the central power and the development of international currency diversification, dollar hegemony is likely to decline but still keep a hardcore position in the international currency market.

\section{References}

[1] Blanchard, Jean-Marc F, and Fujia Lu. "Thinking hard about soft power: A review and critique of the literature on China and soft power." Asian perspective 36.4 (2012): 565-589.

[2] Bordo, Michael, Eric Monnet, and Alain Naef. "The gold pool (1961-1968) and the fall of the Bretton woods system: lessons for Central Bank cooperation." The Journal of Economic History 79.4 (2019): 1027-1059.

[3] Cohen, Benjamin. "Dollarization: pros and cons." workshop 'Dollars, Democracy and Trade: External Influences on Economic Integration in the Americas' Los Angeles. Vol. 18. 2000.

[4] Gourinchas, Pierre-Olivier. "The Dollar Hegemon? Evidence and Implications for Policymakers." THE ASIAN MONETARY POLICY FORUM: Insights for Central Banking. 2021.

[5] Ikenberry, G. John. "3. The Political Origins of Bretton Woods." A Retrospective on the Bretton Woods System. University of Chicago Press, 2007. 155-198.

[6] Milan, Marcelo. "The financial crisis and the dollar hegemony." AUSTRAL: Brazilian Journal of Strategy \& International Relations 1.1 (2012): 125-140.

[7] Mundell, Robert A, “The monetary consequences of Jacques Rueff,” Journal of Business, July 1973, 46 (3), 384-395.

[8] Ouyang, Alice Y., Ramkishen S. Rajan, and Thomas D. Willett. "China as a reserve sink: The evidence from offset and sterilization coefficients." Journal of International Money and Finance 29.5 (2010): 951972.

[9] Prates, Daniela Magalhães, and Marcos Antonio Macedo Cintra. "The emerging-market economies in the face of the global financial crisis." The Financial and economic crisis of 2009 (2008): 53-71. 